\title{
Prevalência De Icterícia Em Pacientes Cirróticos Em Ambulatório Terciário, De Acordo Com Sua Etiologia.
}

\author{
Porto, M.; Mattos, A.A.; John, J.A.; Miozzo, S.A.S.; Comerlato, P.H.; Silva, \\ R.R.; Contiero, P.; \\ Apresentador: Mariana Porto
}

\section{Resumo}

Introdução: A icterícia é um sinal clínico que reflete a perda da função hepatocelular na cirrose. O objetivo deste estudo é avaliar a frequência de icterícia ao início e durante o acompanhamento em um ambulatório de hipertensão portal de um hospital terciário, de acordo com a etiologia da cirrose. Métodos: Foi realizado um estudo coorte, observacional e retrospectivo em todos pacientes com diagnóstico de cirrose com acompanhamento em ambulatório entre março de 2005 a março de 2010 por meio de revisão de prontuários. Foram incluídos todos os pacientes com diagnóstico de cirrose e seguimento mínimo de um ano. Foram excluídos casos de co-infecção com HIV, transplante de órgãos prévio, diagnóstico de carcinoma hepatocelular (CHC) avançado no primeiro atendimento, ausência de registro e perda de seguimento. Critério para definição de icterícia: bilirrubina sérica total ?2,0. Critérios para etiologias: Vírus da Hepatite C (VHC) - anti-HCV + PCR Vírus da Hepatite B (VHB) HBsAg + PCR Álcool - ingestão $>80 \mathrm{~g} / \mathrm{d}$ por 10 anos (homens) ou 40g (mulheres) Outros - diagnóstico histológico ou por exclusão. O projeto foi aprovado pelo CEP institucional. Na comparação de variáveis categóricas utilizamos o teste do qui-quadrado. $\mathrm{O}$ nível de significância do estudo foi de $?=0,05$. Os dados foram analisados com o programa SPSS 18.0. Resultados: Na apresentação ao ambulatório identificou-se icterícia em 152 (29\%) de 527 pacientes. Ao final do acompanhamento, observou-se icterícia em 207 pacientes (39\%). Analisando os grupos pré-definidos, VHC, álcool, VHC + álcool e outros, observamos, no início do acompanhamento: presença de icterícia $(21 \%, 34 \%, 33 \%$ e $32 \%$, respectivamente) com diferença entre o grupo $\mathrm{VHC}$, de menor frequência, em relação aos outros grupos ( $\mathrm{p}$ $=0,034)$. Ao final do acompanhamento $(39 \%, 30 \%$, $48 \%$ e $41 \%$, respectivamente), há diferença entre o grupo álcool, de menor frequência, em relação ao grupo VHC + álcool ( $\mathrm{p}=0,043)$. Conclusão: A alta prevalência de pacientes ictéricos demonstra a gravidade que chegam e evoluem no acompanhamento, refletindo perda da função hepatocelular. Durante o seguimento, o único grupo cujo número total de pacientes com icterícia não aumentou foi o grupo álcool, indicando melhor evolução desses pacientes, provavelmente devido à cessação do hábito.

\section{Referência:}

Porto, M.; Mattos, A.A.; John, J.A.; Miozzo, S.A.S.; Comerlato, P.H.; Silva, R.R.; Contiero, P.;. Prevalência De Icterícia Em Pacientes Cirróticos Em Ambulatório Terciário, De Acordo Com Sua Etiologia.. In: Il Congresso Brasileiro de Medicina Hospitalar - II CBMH [= Blucher Medical Proceedings, vol.1, num.5] São Paulo: Editora Blucher, 2014. p.32 DOI 10.5151/medpro-II-cbmh-025 